\title{
KESESUAIAN RESEP ISPA NON PNEUMONIA DENGAN KRITERIA POR NASIONAL DI PUSKESMAS KABUPATEN SLEMAN YOGYAKARTA
}

\section{Putu Dyana Christasani}

Universitas Sanata Dharma Yogyakarta, Indonesia

Email: putudyana.c@gmail.com

\begin{abstract}
Abstrak
Tenaga kefarmasian di Puskesmas berperan dalam pemantauan dan pembinaan Penggunaan Obat yang Rasional (POR) untuk mencegah dan mengatasi permasalahan dalam pemberian obat. Tingginya penggunaan obat yang tidak rasional serta dampak resistensi yang dapat terjadi, menjadi salah satu dasar penelitian ini perlu dilakukan. Tujuan dari penelitian ini adalah untuk mengetahui kesesuaian peresepan obat ISPA non pneumonia dengan indikator POR Nasional di Puskesmas Kabupaten Sleman, Yogyakarta. Penelitian ini merupakan penelitian observasional deskriptif dengan desain cross-sectional. Data penelitian diperoleh dari resep ISPA non pneumonia periode Januari - Juni 2020. Data dianalisis secara deskriptif dengan menghitung persentase kesesuaian resep ISPA non pneumonia dengan kriteria POR Nasional. Hasil penelitian menunjukkan selama jangka waktu penelitian, pasien yang berkunjung ke Puskesmas didominasi oleh perempuan $(56,45 \%)$ dan dengan kelompok usia 26-45 tahun (26,57\%). Dari 8 Puskesmas di Kabupaten Sleman, hanya 3 Puskesmas $(37,5 \%)$ yang resep ISPA non pneumonia perbulannya yang telah sesuai dengan kriteria POR Nasional. Kesimpulan dari penelitian ini adalah belum semua puskesmas di Kabupaten Sleman, Yogyakarta yang masuk dalam penelitian mampu memenuhi standar rasionalitas peresepan ISPA non pneumonia sesuai dengan kriteria POR Nasional.
\end{abstract}

Kata Kunci: Puskesmas; kriteria POR Nasional; ISPA Non Pneumonia

\section{Abstract}

Pharmacists at the Puskesmas have a role in monitoring and fostering the Rational Use of Drugs (POR) to prevent and overcome the problems in drug administration. The high irrational use of drugs and the bad consequences of resistance is one of the reasons why this research needs to be done. The purpose of this study was to determine the suitability of prescribing non-pneumonia ARI drugs with the National POR indicator at the Sleman District Health Center, Yogyakarta. This research uses observational descriptive research with cross-sectional design. The research data obtained from non-pneumonia ARI prescriptions for the period January-June 2020. Data were analyzed descriptively by calculating the percentage rationality of prescribing non-pneumonia ARI drugs and their conformity with the National POR indicator. The results showed that during the study period, patients who visited the Puskesmas were dominated by women (56.45\%) and the age group was 26-45 years (26.57\%). From 8 Puskesmas in

$\begin{array}{ll}\text { How to cite: } & \text { Christasani, P, D., (2022) Kesesuaian Resep ISPA Non Pneumonia dengan Kriteria Por Nasional di } \\ & \begin{array}{l}\text { Puskesmas Kabupaten Sleman Yogyakarta, Syntax Idea, 4(1), https://doi.org/10.36418/syntax- } \\ \text { idea.v4il.1751 }\end{array} \\ \text { E-ISSN: } & \text { 2684-883X } \\ \text { Published by: } & \text { Ridwan Institute }\end{array}$


Sleman Regency, only 3 Puskesmas (37.5\%) with non-pneumonia ARI prescriptions in each month that met the National POR criteria. This study concludes that not all puskesmas in Sleman Regency, Yogyakarta that included in the study meet the rationality standard for prescribing non-pneumonia ARI by the National POR criteria.

Keywords: Puskesmas; the National POR criteria; non-pneumonia ARI

\section{Received: 2021-12-22; Accepted: 2022-01-05; Published: 2022-01-20}

\section{Pendahuluan}

Puskesmas (Pusat Kesehatan Masyarakat) merupakan fasilitas pelayanan kesehatan untuk masyarakat maupun perseorangan yang mengacu pada upaya promotif dan preventif. Tenaga kefarmasian, baik Apoteker maupun Tenaga Teknis Kefarmasian yang bekerja di Puskesmas wajib memantau penggunaan obat yang rasional untuk mencegah dan mengatasi permasalahan yang terkait obat (Kemenkes RI, 2016). Berdasarkan data (Kemenkes RI, 2018), prevalensi penyakit Infeksi Saluran Pernapasan Akut (ISPA) di Indonesia cukup tinggi yaitu sebesar 9,3\% dan di Provinsi D.I Yogyakarta prevalensi penyakit ISPA sebesar 7\%. Jumlah kasus yang berhubungan dengan penyakit ISPA di Kabupaten Sleman berdasarkan data (Dinkes Sleman, 2018), adalah 103.875 kasus. Tingginya kasus penyakit ISPA di Indonesia dan banyaknya kasus ketidakrasionalan penggunaan antibiotik pada pengobatan ISPA menjadi salah satu pemicu bagi pemerintah untuk menyusun indikator kinerja Penggunaan Obat Rasional (POR) Nasional (Kemenkes, 2017), yang salah satunya menetapkan untuk \% antibiotik $(\mathrm{AB})$ yang diresepkan dokter untuk ISPA non pneumonia tidak boleh lebih dari 20\% (Nofrian Indiarto and Wardani, 2020) (Pulungan et al., 2019).

Beberapa penelitian terdahulu menunjukkan bahwa belum semua Puskesmas mampu memenuhi indikator yang ditetapkan dalam POR Nasional. Berdasarkan penelitian (Nofrian Indiarto and Wardani, 2020), rata-rata peresepan antibiotik di Puskesmas Kabupaten Sidoarjo, Jawa Timur tahun 2017 sebesar 46,22\%. Nilai ini jauh lebih tinggi dibandingkan standar yang ditetapkan dalm POR Nasional. Menurut penelitian (Pulungan et al, 2019), rata-rata peresepan antibiotik pada diagnosa ISPA non pneumonia selama tahun 2017 sebesar 51,76\%. Peresepan yang tidak rasional dapat memberi dampak negatif bagi masyarakat, salah satunya adalah resistensi antibiotika. Banyak pasien ISPA non pneumonia yang masih mendapat resep antibiotika walaupun belum dapat dipastikan bahwa penyebab ISPA yang dialami diakibatkan oleh infeksi bakteri. Jika seseorang mengalami resistensi antibiotika, dikhawatirkan saat mengalami infeksi bakteri, tidak ada lagi antibiotik yang mampu membunuh bakteri penyebab infeksi tersebut (Andrajati, Tilaqza, and Supardi, 2017) (Masrifany and Sari, 2021).

Kabupaten Sleman merupakan Kabupaten di Provinsi D.I Yogyakarta yang memiliki jumlah penduduk terbanyak yaitu 1.087.339 jiwa berdasarkan data Dinas Kependudukan Provinsi D.I Yogyakarta tahun 2021 (Jogjaprov, 2021). Kabupaten Sleman memiliki 25 Puskesmas yang tersebar di setiap Kecamatan. Tingginya 
prevalensi penyakit ISPA dan banyaknya jumlah penduduk di Kabupaten Sleman, menyebabkan perlunya perhatian dan evaluasi terhadap peresepan obat-obat untuk penyakit ISPA. Penelitian ini bertujuan untuk mengevaluasi kesesuaian peresepan obat untuk penyakit ISPA non pneumonia di Puskesmas di Kabupaten Sleman, Yogyakarta berdasarkan kriteria POR Nasional. Hasil penelitian ini diharapkan dapat digunakan sebagai bahan evaluasi untuk peresepan obat ISPA non pneumonia di Puskesmas serta dapat memberi masukan bagi tenaga kesehatan yang ada di Puskesmas untuk memperperbaiki kualitas peresepan obat untuk penyakit ISPA non pneumonia.

\section{Metode Penelitian}

Penelitian ini merupakan penelitian observasional deskriptif dengan desain crosssectional. Data penelitian diperoleh secara restrospektif dengan mengambil data resep untuk ISPA non pneumonia periode Januari-Juni 2020. Tempat penelitian dipilih menggunakan cluster sampling dengan mengambil delapan puskesmas yang ada di Kabupaten Sleman, Yogyakarta. Kriteria Inklusi dalam penelitian ini yaitu: resep dengan diagnosis ISPA non pneumonia atau jenis penyakit ISPA termasuk common cold, batuk pilek, otitis media serosa akut, atau sinusitis non infeksi bakteri; resep lengkap secara administratif (jenis kelamin, usia, berat badan pasien [khususnya pada anak usia <12 tahun], dan nama obat). Kriteria eksklusi dalam penelitian ini yaitu: resep ISPA non pneumonia dengan penyakit penyerta infeksi; resep dengan tulisan yang tidak dapat terbaca. Data dianalisis dengan cara menghitung jumlah resep yang mengandung antibiotika perbulan, kemudian ditampilkan dalam bentuk persentase. Resep ISPA non pneumonia setiap bulannya dikatakan sesuai dengan kriteria POR Nasional jika memiliki persentase resep yang mengandung antibiotika kurang dari sama dengan $20 \%$.

\section{Hasil dan Pembahasan}

Penelitian ini menggunakan 7.438 resep obat yang memenuhi kriteria inklusi dan eksklusi penelitian. Data karakteristik responden penerima resep selama periode Januari-Juni 2020 ditunjukkan pada tabel I.

\section{Tabel I}

Karakteristik Responden Penerima Resep

\begin{tabular}{lcc}
\hline \multicolumn{1}{c}{ Karakteristik } & \multicolumn{2}{c}{$\begin{array}{c}\text { Jumlah } \\
(\mathbf{n = 7 4 3 8})\end{array}$} \\
\cline { 2 - 3 } & n & \% \\
\hline Usia & & \\
$0-11$ tahun & 895 & 12,03 \\
$12-25$ tahun & 1873 & 25,18 \\
$26-45$ tahun & 1976 & 26,57 \\
$46-65$ tahun & 1834 & 24,66 \\
$>65$ tahun & 860 & 11,56 \\
\hline Jenis kelamin & & \\
Laki-laki & 3239 & 43,55 \\
Perempuan & 4199 & 56,45 \\
\hline
\end{tabular}


Berdasarkan data (Kemenkes RI, 2018), penyakit ISPA termasuk dalam 10 penyakit dengan prevalensi tertinggi di Kabupaten Sleman. Dapat dilihat dari hasil penelitian, dari 8 Puskesmas yang digunakan sebagai tempat penelitian terdapat 7.438 resep untuk mengatasi ISPA. Berdasarkan tabel I diketahui bahwa persentase kunjungan pasien tertinggi yaitu kelompok usia 26-45 tahun (dewasa) sebesar 26,57\%. Semua kelompok usia memiliki risiko yang sama untuk mengalami ISPA, namun semakin meningkatnya usia, risiko tersebut semakin rendah. Seseorang dengan riwayat asma memiliki risiko yang lebih tinggi untuk mengalami ISPA (Oliver et al., 2014).

Profil jenis kelamin pasien menggambarkan kasus ISPA dialami baik oleh lakilaki maupun perempuan. Jumlah kunjungan pasien ISPA yang paling tinggi adalah dari pasien berjenis kelamin perempuan (56,45\%). Berdasarkan (Groeneveld et al, 2021), diketahui bahwa perempuan memiliki frekuensi yang lebih sering untuk mengunjungi dokter ketika mengalami gejala pada saluran pernapasan. Perempuan memiliki sikap peduli terhadap kesehatan yang lebih tinggi dibandingkan laki-laki. Pada kasus tertentu jenis kelamin mempengaruhi terjadinya penyakit akan tetapi pada penelitian ini jenis kelamin tidak memberikan perbandingan yang jauh berbeda. Perempuan dan laki-laki memiliki resiko yang sama untuk mengalami ISPA (Fibrilia, 2015), (JD et al., 2017).

Penggunaan obat dikatakan rasional jika pasien menerima obat yang sesuai dengan dibutuhkannya, untuk periode waktu yang adekuat dan dengan harga yang paling terjangkau untuk pasien dan masyarakat (Andrajati et al., 2017). Identifikasi masalah dan monitoring serta evaluasi POR dilakukan berdasarkan susunan indikator. Salah satu indikator yang ditetapkan adalah persentase peresepan antibiotik pada ISPA non pneumonia $\leq 20 \%$ (Graham et al., 2016) (Kose and Colak, 2021). Pada tabel II telah tersaji hasil kesesuaian peresepan ISPA non pneumonia dengan indikator POR Nasional.

Tabel 2

Kesesuaian Resep dengan Indikator POR Nasional

\begin{tabular}{|c|c|c|c|c|c|c|}
\hline \multirow[t]{2}{*}{ Puskesmas } & \multirow[t]{2}{*}{ Bulan } & \multicolumn{2}{|c|}{$\begin{array}{c}\text { Resep } \\
\text { mengandung AB }\end{array}$} & \multicolumn{2}{|c|}{ Resep tanpa AB } & \multirow[t]{2}{*}{ Kesimpulan } \\
\hline & & $\mathbf{n}$ & $\%$ & n & $\%$ & \\
\hline \multirow[t]{6}{*}{ I } & Januari & 20 & $90,91 \%$ & 2 & $9,09 \%$ & Tidak sesuai \\
\hline & Februari & 33 & $84,62 \%$ & 6 & $15,38 \%$ & Tidak sesuai \\
\hline & Maret & 28 & $82,35 \%$ & 6 & $17,65 \%$ & Tidak sesuai \\
\hline & April & 24 & $92,31 \%$ & 2 & $7,69 \%$ & Tidak sesuai \\
\hline & Mei & 15 & $83,33 \%$ & 3 & $16,67 \%$ & Tidak sesuai \\
\hline & Juni & 27 & $84,38 \%$ & 5 & $15,63 \%$ & Tidak sesuai \\
\hline \multirow[t]{6}{*}{ II } & Januari & 5 & $3,94 \%$ & 122 & $96,06 \%$ & Sesuai \\
\hline & Februari & 8 & $3,32 \%$ & 233 & $96,68 \%$ & Sesuai \\
\hline & Maret & 11 & $5,50 \%$ & 189 & $94,50 \%$ & Sesuai \\
\hline & April & 12 & $6,82 \%$ & 164 & $93,18 \%$ & Sesuai \\
\hline & Mei & 4 & $2,45 \%$ & 159 & $97,55 \%$ & Sesuai \\
\hline & Juni & 13 & $7,65 \%$ & 157 & $92,35 \%$ & Sesuai \\
\hline
\end{tabular}




\begin{tabular}{|c|c|c|c|c|c|c|}
\hline \multirow[t]{2}{*}{ Puskesmas } & \multirow[t]{2}{*}{ Bulan } & \multicolumn{2}{|c|}{$\begin{array}{c}\text { Resep } \\
\text { mengandung } \mathrm{AB}\end{array}$} & \multicolumn{2}{|c|}{ Resep tanpa AB } & \multirow[t]{2}{*}{ Kesimpulan } \\
\hline & & n & $\%$ & $\mathbf{n}$ & $\%$ & \\
\hline \multirow[t]{6}{*}{ III } & Januari & 11 & $9,60 \%$ & 103 & $90,40 \%$ & Sesuai \\
\hline & Februari & 15 & $6,30 \%$ & 222 & $93,70 \%$ & Sesuai \\
\hline & Maret & 15 & $6,60 \%$ & 213 & $93,40 \%$ & Sesuai \\
\hline & April & 21 & $12,40 \%$ & 148 & $87,60 \%$ & Sesuai \\
\hline & Mei & 20 & $10,30 \%$ & 175 & $89,70 \%$ & Sesuai \\
\hline & Juni & 22 & $12,2 \%$ & 158 & $87,80 \%$ & Sesuai \\
\hline \multirow[t]{6}{*}{ IV } & Januari & 12 & $13,20 \%$ & 79 & $86,80 \%$ & Sesuai \\
\hline & Februari & 13 & $11,90 \%$ & 96 & $88,10 \%$ & Sesuai \\
\hline & Maret & 21 & $25,30 \%$ & 62 & $74,70 \%$ & Tidak sesuai \\
\hline & April & 10 & $7,90 \%$ & 116 & $92,10 \%$ & Sesuai \\
\hline & Mei & 7 & $5,80 \%$ & 113 & $94,20 \%$ & Sesuai \\
\hline & Juni & 10 & $8,80 \%$ & 103 & $91,20 \%$ & Sesuai \\
\hline \multirow[t]{6}{*}{$\mathrm{V}$} & Januari & 11 & $6,01 \%$ & 172 & $93,99 \%$ & Sesuai \\
\hline & Februari & 2 & $1,04 \%$ & 191 & $98,96 \%$ & Sesuai \\
\hline & Maret & 4 & $2,31 \%$ & 169 & $97,69 \%$ & Sesuai \\
\hline & April & 2 & $1,20 \%$ & 164 & $98,80 \%$ & Sesuai \\
\hline & Mei & 2 & $1,85 \%$ & 106 & $98,15 \%$ & Sesuai \\
\hline & Juni & 3 & $2,26 \%$ & 130 & $97,74 \%$ & Sesuai \\
\hline \multirow[t]{6}{*}{ VI } & Januari & 7 & $4,43 \%$ & 151 & $95,57 \%$ & Sesuai \\
\hline & Februari & 5 & $3,85 \%$ & 125 & $96,15 \%$ & Sesuai \\
\hline & Maret & 12 & $6,22 \%$ & 181 & $93,78 \%$ & Sesuai \\
\hline & April & 24 & $17,91 \%$ & 110 & $82,09 \%$ & Sesuai \\
\hline & Mei & 36 & $21,43 \%$ & 132 & $78,57 \%$ & Tidak sesuai \\
\hline & Juni & 29 & $25,44 \%$ & 85 & $74,56 \%$ & Tidak sesuai \\
\hline \multirow[t]{6}{*}{ VII } & Januari & 58 & $19 \%$ & 247 & $81 \%$ & Sesuai \\
\hline & Februari & 42 & $10,66 \%$ & 352 & $89,34 \%$ & Sesuai \\
\hline & Maret & 35 & $12,46 \%$ & 246 & $87,54 \%$ & Sesuai \\
\hline & April & 22 & $12,72 \%$ & 151 & $87,28 \%$ & Sesuai \\
\hline & Mei & 45 & $23,32 \%$ & 148 & $76,68 \%$ & Tidak sesuai \\
\hline & Juni & 21 & $16,67 \%$ & 105 & $83,33 \%$ & Sesuai \\
\hline \multirow[t]{6}{*}{ VIII } & Januari & 23 & $14,46 \%$ & 136 & $85,54 \%$ & Sesuai \\
\hline & Februari & 43 & $19,20 \%$ & 181 & $80,80 \%$ & Sesuai \\
\hline & Maret & 51 & $22,47 \%$ & 176 & $77,53 \%$ & Tidak sesuai \\
\hline & April & 28 & $15,73 \%$ & 150 & $84,27 \%$ & Sesuai \\
\hline & Mei & 39 & $20,97 \%$ & 147 & $79,03 \%$ & Tidak sesuai \\
\hline & Juni & 16 & $12,50 \%$ & 112 & $87,50 \%$ & Sesuai \\
\hline
\end{tabular}

Keterangan:

$* \mathrm{AB}=$ Antibiotik

* Kesesuaian Resep dengan Indikator POR Nasional jika memiliki \% peresepan antibiotic $\leq 20 \%$

Penggunaan antibiotika dengan persentase yang tidak sesuai dengan ketentuan POR Nasional ini tentu dapat mengakibatkan munculnya dampak negatif. Menurut, 
dampak dari penggunaan obat yang tidak rasional adalah meningkatnya resiko efek samping atau efek lain yang tidak diharapkan. Selain itu akibat dari pemberian antibiotika pada kondisi yang bukan merupakan indikasinya (misalnya infeksi yang disebabkan oleh virus) dapat menyebabkan terjadinya resistensi kuman terhadap antibiotika (Aslam et al. 2018) (Dahesihdewi, Sugianli, and Parwati, 2019).

Berdasarkan hasil penelitian, hanya 3 dari 8 Puskesmas $(37,5 \%)$ telah memenuhi kriteria POR Nasional untuk peresepan ISPA non pneumonia. Penelitian ini hanya menggunakan data resep yang diperoleh dari Puskesmas pada bulan Januari - Juni 2020. Hal ini menjadi keterbatasan bagi peneliti dimana peneliti tidak dapat menelusuri riwayat penyakit pasien melalui data rekam medis. Berdasarkan penelitian (Insani and Permana, 2020) dan (Chow et al, 2012), antibiotik boleh diresepkan untuk penyakit ISPA non pneumonia apabila kondisi tersebut disebabkan oleh infeksi bakteri, dengan gejala menetap lebih dari 10 hari, demam yang tinggi $\geq 39^{\circ} \mathrm{C}$, sekret nasal, serta muncul perburukan gejala. Kemungkinan responden yang memperoleh antibiotik merupakan pasien yang memiliki gejala-gejala yang dapat mencerminkan diagnosis lainnya, misalnya dugaan infeksi.

Pemberian antibiotik tanpa pemeriksaan mikrobiologis dapat didasarkan pada profesionalisme dan kompetensi tenaga kesehatan yang bertugas. Oleh sebab itu diperlukan diagnosis rasional dari dokter sehingga pengobatan yang diberikan sesuai kebutuhan pasien (Rost et al. 2021) (Shaver et al. 2019). Menurut (Djulbegovic, Elqayam and Dale, 2018), pengambilan keputusan rasional tergantung pada pemilihan teori untuk situasi klinis tertentu. Pilihan teori yang beragam dapat mempengaruhi pengambilan keputusan oleh dokter. Hal ini juga dapat menunjukkan bahwa apa yang dianggap rasional di dalam satu teori keputusan mungkin tidak dianggap rasional oleh teori yang berbeda. Melihat hal tersebut, maka antibiotik dapat diberikan dengan mempertimbangkan diagnosis rasional (Cave, 2017). Salah satu keterbatasan dalam pada penelitian ini yaitu tidak melakukan wawancara kepada dokter dan tidak mempertimbangkan alasan peresepan antibiotik. Keterbatasan ini menyebabkan peneliti tidak dapat menelaah lebih jauh dalam menyikapi privilege of rational judgement yang dilakukan dokter.

Berdasarkan Pedoman Pengobatan Klinik yang dikeluarkan oleh Ikatan Dokter Indonesia (IDI), pada kasus rhinitis alergi, common cold dan laringitis dengan infeksi sekunder bakteri, pasien perlu mendapat tambahan antibiotika. Begitu pula pengobatan sinusitis dan otitis media akut diperlukan antibiotik dalam pengobatannya (Ambarwati, Setiawaty, and Wibowo 2018) (Thobari et al., 2019). Berdasarkan hal tersebut memungkinkan adanya peresepan antibiotik apabila dirasakan perlu untuk penyakitpenyakit tersebut. Dari hal-hal yang sudah dianalisa tersebut, pemilihan penggunaan terapi antibiotik pada kasus ISPA non pneumonia sangat tergantung dari kondisi klinis pasien. Penting juga untuk memperhatikan catatan medis pasien dan hasil pemeriksaan laboratorium sehingga penggunaan terapi antibiotik dapat menjadi lebih tepat dan rasional. 


\section{Kesimpulan}

Kesimpulan dari penelitian ini adalah pasien yang berkunjung ke Puskesmas didominasi oleh perempuan $(56,45 \%)$ dan dengan kelompok usia 26-45 tahun $(26,57 \%)$. Hanya 3 dari 8 Puskesmas $(37,5 \%)$ dengan peresepan ISPA non pneumonia perbulan yang telah sesuai dengan kriteria POR Nasional.

\section{BIBLIOGRAFI}

Ambarwati, Wiwi, Vivi Setiawaty, and Adik Wibowo. 2018. "Antibiotics Used for Upper Respiratory Tract Infection: A Case Study at a Primary Health Center Bogor Indonesia." Global Medical \& Health Communication (GMHC) 6(3):22632.Google Scholar

Andrajati, Retnosari, Andri Tilaqza, and Sudibyo Supardi. 2017. "Factors Related to Rational Antibiotic Prescriptions in Community Health Centers in Depok City, Indonesia." Journal of Infection and Public Health 10(1):41-48. Google Scholar

Aslam, Bilal, Wei Wang, Muhammad Imran Arshad, Mohsin Khurshid, Saima Muzammil, Muhammad Hidayat Rasool, Muhammad Atif Nisar, Ruman Farooq Alvi, Muhammad Aamir Aslam, Muhammad Usman Qamar, Muhammad Khalid Farooq Salamat, and Zulqarnain Baloch. 2018. "Antibiotic Resistance: A Rundown of a Global Crisis." Infection and Drug Resistance 11:1645-58. Google Scholar

Cave, Emma. 2017. "The Ill-Informed: Consent to Medical Treatment and the Therapeutic Exception." Common Law World Review 46(2):140-68. Google Scholar

Chow, Anthony W., Michael S. Benninger, Itzhak Brook, Jan L. Brozek, Ellie J. C. Goldstein, Lauri A. Hicks, George A. Pankey, Mitchel Seleznick, Gregory Volturo, Ellen R. Wald, and Thomas M. File. 2012. "Executive Summary: IDSA Clinical Practice Guideline for Acute Bacterial Rhinosinusitis in Children and Adults." Clinical Infectious Diseases 54(8):1041-45. Google Scholar

Dahesihdewi, Andaru, Adhi Kristianto Sugianli, and Ida Parwati. 2019. "The Surveillance of Antibiotics Resistance in Indonesia: A Current Reports." Bali Medical Journal 8(2):565. Google Scholar

Dinkes Sleman. 2018. Profil Kesehatan Kabupaten Sleman Tahun 2018. Sleman, Yogyakarta: Dinas Kesehatan Kabupaten Sleman.

Djulbegovic, Benjamin, Shira Elqayam, and William Dale. 2018. "Rational Decision Making in Medicine: Implications for Overuse and Underuse." Journal of Evaluation in Clinical Practice 24(3):655-65. Google Scholar

Fibrilia, Firda. 2015. "Hubungan Usia Anak, Jenis Kelamin Dan Berat Badan Lahir Anak Dengan Kejadian Pneumonia." Jurnal Kesehatan Metro Sai Wawai VIII(2):8-13. Google Scholar 
Graham, Kirstie, Chomba Sinyangwe, Sarala Nicholas, Rebecca King, Samuel Mukupa, Karin Källander, Helen Counihan, Mark Montague, James Tibenderana, and Prudence Hamade. 2016. "Rational Use of Antibiotics by Community Health Workers and Caregivers for Children with Suspected Pneumonia in Zambia: A Cross-Sectional Mixed Methods Study." BMC Public Health 16(1):897. Google Scholar

Groeneveld, Johanna M., Aranka V. Ballering, Kees van Boven, Reinier P. Akkermans, Tim C. Olde Hartman, and Annemarie A. Uijen. 2021. "Sex Differences in Incidence of Respiratory Symptoms and Management by General Practitioners." Family Practice 37(5):631-36. Google Scholar

Insani, Mirza, and Dharma Permana. 2020. "Use of Antibiotics for Acute Respiratory Infection (ARI) in Puskesmas Karang Rejo, Tarakan." Yarsi Journal of Pharmacology 1(1):15-21. Google Scholar

JD, Owens, Hicks Harper PT, Reynolds SD, Ibama AS, Dozie INS, Abanobi OC, Amadi AN, Iwuoha G, Jaja T, and Dennis P. 2017. "The Relationship of Gender in the Pattern and Risk of Acute Respiratory Infection among Infants in Rivers State, Nigeria." Journal of Community Medicine \& Health Education 07(06):1-6. Google Scholar

Jogjaprov. 2021. "Jumlah Penduduk DI Yogyakarta SEMESTER I 2021 Menurut Jenis Kelamin.” Dinas Kependudukan Provinsi Daerah Istimewa Yogyakarta. Retrieved January 7, 2022 (https://kependudukan.jogjaprov.go.id/).

Kemenkes. 2017. Kebijakan Peningkatan Penggunaan Obat Rasional (POR). Jakarta: Dirjen Kefarmasian dan Alat Kesehatan.

Kemenkes RI. 2016. Peraturan Menteri Kesehatan Republik Indonesia Nomor 74 Tahun 2016 Tentang Standar Pelayanan Kefarmasian Di Puskesmas. Jakarta: Kementerian Kesehatan RI.

Kemenkes RI. 2018. Hasil Riset Kesehatan Dasar Tahun 2018. Vol. 53. Jakarta: Kementerian Kesehatan RI. Google Scholar

Kose, Adem, and Cemil Colak. 2021. "Knowledge and Awareness of Physicians About Rational Antibiotic Use and Antimicrobial Resistance Before and After Graduation: A Cross-Sectional Study Conducted in Malatya Province in Turkey." Infection and Drug Resistance Volume 14:2557-68. Google Scholar

Masrifany, G. V, and D. P. Sari. 2021. "Penggunaan Obat Rasional Di Jawa Timur." Seminar Nasional Hasil Riset Dan Pengabdian 3(1):2018-21.

Nofrian Indiarto, Erick, and Susilo Ari Wardani. 2020. "Profil Penggunaan Obat Rasional Di Puskesmas Kabupaten Sidoarjo Provinsi Jawa Timur Tahun 2017.” CALYPTRA 9(1). Google Scholar 
Oliver, Brian G. G., Paul Robinson, Mathew Peters, and Judy Black. 2014. "Viral Infections and Asthma: An Inflammatory Interface?" European Respiratory Journal 44(6):1666-81. Google Scholar

Pulungan, Rodiahti, Adek Chan, Ella Fransiska, Mahasiswa Farmasi, Fakultas Farmasi, Kesehatan Umum, Institut Kesehatan Helvetia, and Dosen Farmasi. 2019. "Evaluasi Penggunaan Obat Rasional Di Puskesmas Kabupaten Serdang Bedagai." Jurnal Dunia Farmasi 3(3):144-52. Google Scholar

Rost, Lauren M., M. Hong Nguyen, Cornelius J. Clancy, Ryan K. Shields, and Erik S. Wright. 2021. "Discordance among Antibiotic Prescription Guidelines Reflects a Lack of Clear Best Practices." Open Forum Infectious Diseases 8(1). Google Scholar

Shaver, Amy L., David M. Jacobs, Michael J. Lamonte, and Katia Noyes. 2019. "Antibiotic Prescribing for Acute Respiratory Tract Infections in the United States Outpatient Setting." BMC Family Practice 20(1):91. Google Scholar

Thobari, Jarir At, Cahya Dewi Satria, Yohanes Ridora, Emma Watts, Amanda Handley, Samad Samad, Novilia S. Bachtiar, Julie E. Bines, Yati Soenarto, and Jim P. Buttery. 2019. "Antimicrobial Use in an Indonesian Community Cohort 0-18 Months of Age." PLoS ONE 14(8). Google Scholar

\section{Copyright holder:}

Putu Dyana Christasani (2022)

\section{First publication right:}

Syntax Idea

This article is licensed under: 